\title{
On Some Aspects of Territorial Competitiveness: Smart Specialization in the Zlín 2020 Strategy
}

\author{
Novosák Jirǔ, Hájek Oldrich, Zabradník Petr, Nekolová Jana
}

\begin{abstract}
Territorial competitiveness is a development concept often cited these days. Currently, smart specialization represents a politically influential concept how to stimulate territorial competitiveness. This article deals with some relations between smart specialization on the one hand and territorial competitiveness on the other. In particular, the main goal of this article is to introduce how these relations were reflected in the case study of the Zlín City Development Strategy for the years 2014-2020. In this regard, the smart specialization concept was used as the leading concept for formulating strategic goals and measures related to economic development and labour market of the city. The article combines findings from both analytical and strategic parts of the document. Overall, some methodological inspiration may be drawn.
\end{abstract}

Keywords: territorial competitiveness, smart specialization, strategic planning, Zlin

\section{INTRODUCTION}

There is a long-term interest in the concept of territorial competitiveness. However, a consensus on a definition of the term is missing (see e.g. Benzaquen et al., 2012; Kitson et al., 2004). Dudensing (2008) distinguishes two different approaches in this regard. The first approach is focused on territorial productivity. Thus, territories are competitive if they are able to increase their outputs compared to inputs. The second approach is a broader one because it adds a number of other factors, such as infrastructure, human capital or innovations, to the territorial competitiveness concept. Note that territorial competitiveness is our first theoretical concept of this article. Because of its political prominence, there is a large body of literature on various factors of territorial competitiveness now (see e.g. Nijkamp, 2009). These include also the modern smart specialization concept which has experienced a relatively short but exciting life so far (see Foray, David and Hall, 2011). What is the rationale of this concept? McCann and Ortega-Argilés (2011) mention two typical features in this regard:

- First, smart specialization emphasizes the importance of activities which absorb and spread innovations produced in core R\&D centres.

- Second, the success of smart specialization is strengthened by the sector size and linkages between actors.

In addition, McCann and Ortega-Argilés (2011) point at close relations between the smart specialization and place-based development concepts. They claim that public financing is desirable to remove development traps of particular territories and that stimulation of actors on the basis of smart specialization is regarded as a suitable strategy. Thus, smart specialization and its relations to territorial competitiveness are the second key theoretical concept of this article. 
Finally, the programming principle is our third key theoretical concept. The essence of this principle claims that program-based development may create a desirable thematic coherence which is not achievable from isolated, not inter-linked projects (see e.g. Bourne, 2007). It is noteworthy that the European Union (the EU hereafter) cohesion policy is based, among others, just on the programming principle. In practice, the so called Common Strategic Framework provides strategic guidelines on further development of the EU territory through cohesion policy interventions. For our article it is crucial that this strategic document emphasizes the importance of smart specialization as a source of territorial competitiveness (see EC, 2012; Camagni and Capello, 2013).

Altogether, the nexus of territorial competitiveness, smart specialization, and programming was closed. And just relations between territorial competitiveness and smart specialization in the context of the programming principle are the subject of our interest in this article. Our main goal is to introduce how these relations were reflected in the Zlín City Development Strategy 20142020 (the Zlín 2020 Strategy hereafter). Note that the authors of this article played the leading role in formulation of this development strategy.

The article is structured as follows. The second chapter provides some theoretical insights into relations between territorial competitiveness and smart specialization, respecting the importance of strategic approach. The third chapter introduces our analytical approach for studying assumptions of smart specialization in the Zlín 2020 Strategy. Subsequently, the implementation process of our analytical findings into the development proposal of the Zlín 2020 Strategy is sketched out. The last chapter concludes.

\section{LITERATURE REVIEW}

In the EU, there is a broad political debate on the impact of spatially concentrated innovationbased specialization on territorial competitiveness now. These include, among others, the influential Barca's report (see Barca, 2009) or one of the EU flagship initiatives called "Innovation Union" (see EC, 2010). Consequently, the concept of smart specialization has become one of the leading concepts how to increase the EU competitiveness in its EU 2020 strategy (see e.g. EC, 2012 or Foray, David and Hall, 2011 for the importance of the smart specialization concept).

The rationale of the smart specialization concept is based on two assumptions (see Foray, David and Hall, 2011; McCann and Ortega-Argilés, 2011):

- First, the smart specialization concept claims that territories may not be engaged in all R\&D activities because of their limited resources. Thus, territorial specialization in the most promising innovative domains is highly desirable. In other words, territories support their unique knowledge base as a source of innovation and territorial competitiveness.

- Second, the smart specialization concept aspires to grasp benefits arising from economies of scale and knowledge spillovers in territories. In other words, sector size and linkages between actors are essential to fully utilize fruitful benefits from smart specialization.

There is a rather strong theoretical underpinning of the aforementioned assumptions. Thus, innovations are regarded as a key ingredient of territorial development in a number of theoretical concepts. These include, among others, the concepts of innovative milieu (e.g. Maillat, 1998), clusters (see e.g. Pavelková and Jirčíková, 2008; Žižka, 2008), or regional innovation systems (see 
e.g. Skokan, 2010; or Isaksen, 2001). Similarly, economies of scale and knowledge spillovers are cornerstones of e.g. the agglomeration economies or industrial district concepts. In this way of reasoning, territory-based benefits are derived from input-output relations of economic subjects, from common labor market, and from information exchange (tacit knowledge and social capital). One type of agglomeration economies - economies of localization - is specifically focused on benefits arising from specialization in one industry (see e.g. Phelps, 2004). It is noteworthy that a better ability to innovate is regarded as a positive impact of agglomeration economies (see e.g. Scott and Storper, 2003).

There are differences between particular types of territories in their assumptions for practical implementation of the smart specialization concept. Naturally, core territories with their strong innovation bases have the best assumptions in this regard (see e.g. Camagni and Capello, 2013). Nevertheless, the smart specialization concept is highly relevant also for peripheral territories characterized by a small specialized market on one hand and limited linkages between actors on the other (McCann and Ortega-Argilés, 2011). McCann and Ortega-Argilés (2011) speak about innovation-based diversification of traditional, locally embedded, large scale industries as the way how to implement the smart specialization concept in this type of territories. Note that the innovation-based diversification of regional specialization may be regarded also as the way how to escape the lock-in threads (compare e.g. with Grabher, 1993)

Finally, what are the political implications which may be drawn from the smart specialization concept? Foray, David and Hall (2011), McCann and Ortega-Argilés (2011) give the following points in this regard:

- Territories need to identify or "discover" the technological domains which are likely sources of competitive advantage in future. Thus, it is necessary to identify knowledge intensive domains (e.g. ICT) with a high growth potential but simultaneously considering inherited territorial structures such as economic basis. Note that smart domains are expected to be supported in their early development phase.

- Territories support spatial knowledge diffusion on the basis of linkage creation between actors (e.g. linkages between R\&D subjects and firms, supply chains and others) including interregional linkages (see also Camagni and Capello, 2013 for this argument). In this way, human capital relevant for the smart specialization concept is also developed. The relationship between smart specialization and labour market is noteworthy.

Altogether, the importance of the smart specialization concept for territorial development seems to be well substantiated. Moreover, the current practice of territorial development upholds the importance of programming approach. Thus, thematic coherence of particular projects is searched and subsequently embedded in programming documents. In this regard, the nature of the smart specialization concept represents a suitable framework how to ensure such coherence. The abovementioned arguments represent a fundamental theoretical framework how to involve the smart specialization concept into the Zlín 2020 Strategy.

\section{THE ZLÍN 2020 STRATEGY}

The Zlín 2020 Strategy was elaborated as a fundamental conceptual document of the Zlín City for the period 2014-2020. The document was completed at the end of 2012. Its content respects 
the traditional structure of strategic documents. First, analytical part defines the main development strengths, weaknesses, opportunities and barriers of the Zlín City in particular thematic areas. Subsequently, development vision, strategic goals and measures are formulated for each thematic area. Naturally, it is out of the scope of this article to introduce all aspects connected with elaboration of this strategy. Instead, our focus is just on the issue of smart specialization.

\subsection{Smart specialization in the Zlín 2020 Strategy - analytical part}

The analytical part of the Zlín 2020 Strategy respects the fact that the Zlín region may be regarded as the peripheral region not only in the European but also in the Czech context. Thus, the approach coined by McCann and Ortega-Argilés (2011) - innovation-based diversification of traditional, locally embedded, large scale industries - was chosen. Two areas of analytical work may be regarded as relevant in this regard - assessment of innovative environment and of territorial specialization. Note that we decided not to restrict our interest territory by administrative boundaries of the Zlín City because economic development has its wider spatial relations. Thus, our analysis is related to administrative territories of three municipalities with extended power - Zlín, Otrokovice and Vizovice (the Zlín agglomeration hereafter).

Let us turn our attention to the assessment of current territorial specialization in the Zlín agglomeration. First, we compiled a database of 880 economic subjects which met two conditions, the economic subject has more than 10 employees and its seat of residence is in the Zlín agglomeration. Note that subjects of public and non-profit sectors were excluded from the analysis. On the other hand, we added subjects with seat of residence outside the Zlín agglomeration if they employed more than 200 employees in the Zlín agglomeration. We used the commercial database Albertina and Register of Economic Subjects of the Czech Statistical Office as the data-sources. Thus, the state in the year 2011 is depicted. Tab. 1 gives the review of attributes which were followed for economic subjects in the database.

Tab. 1 - Review of attributes. Source: own elaboration.

\begin{tabular}{|l|l|}
\hline Attribute & Values \\
\hline $\begin{array}{l}\text { Industry of prevailing } \\
\text { activities }\end{array}$ & NACE-CZ codes (three digits) \\
\hline Number of employees & Categories - the middle value \\
\hline Turnover & Categories - the middle value \\
\hline
\end{tabular}

Second, we calculated the structure of industries according to their shares on the number of economic subjects, on the number of employees, and on turnovers. Fig. 1 gives top five industries of the three evaluations. The findings point at two relatively strong industries in the structure of the Zlín agglomeration, in particular plastics industry and rubber production. Thus, territorial specialization seems to be related especially to these two industries (compare also with Hájek, Novosák and Hovorková, 2011). On the contrary, there are no signs of territorial specialization of the Zlín agglomeration in other industries (see Fig. 1). However, three other industries with relatively better assumptions were explicitly mentioned for the smart specialization concept despite their position is not as strong as in the case of plastics industry and rubber production. These industries include metalworking and machinery because of their relatively higher number 
of larger economic subjects and importance for employment, and ICT programming because of their relatively higher number of larger economic subjects.

Third, we assessed also some aspects related to development dynamics of the abovementioned industries. Thus, changes in added values in the period 2007-2010 were analyzed. The year 2007 was selected as the base year. Accounting documents of particular firms were the main source of information. Data were compiled for 434 economic subjects from the database. However, we would like to stress that our evaluation must be interpreted with caution because of incomplete sample of analyzed firms, because of a relatively short period evaluated and because of the influence of the base year 2007. Nevertheless, some interesting findings may be drawn (see Fig. 2). Rubber production and ICT programming show the ability to recover from the economic crisis of the late 2000s. These are only two industries which generated higher added value in $2010 \mathrm{com}-$ pared with the base year 2007. It is also noteworthy that rubber production in the Zlín agglomeration tends to have better figures than the whole industry in the Czech Republic. Machinery seems to be most seriously hit by the economic crisis of the late 2000s. Such a decline was not experienced by any other analyzed industry.

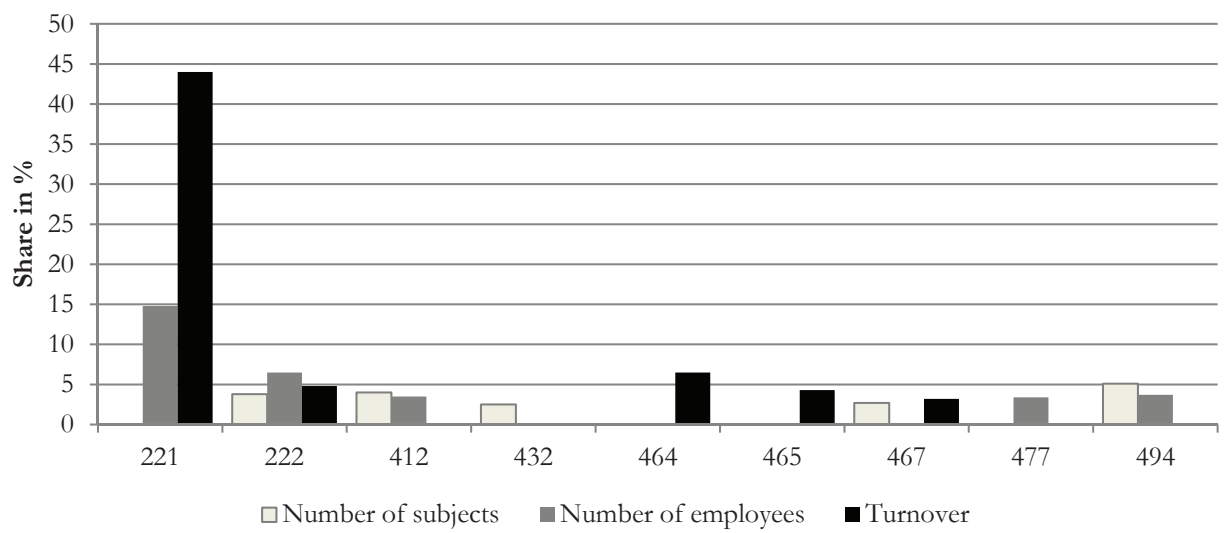

Note: 221 - Rubber production; 222 - Plastics industry; 412 - Construction; 432 - Installation works; 464 - Wholesaling with household products; 465 - Wholesaling with ICT products; 467 - Other specialized wholesaling; 477 - Retailing with other products; 494 - Road freight transport

Fig. 1 - Top five industries in the Zlin agglomeration according to selected criteria (2011). Source: own elaboration based on Albertina and Register of Economic Subjects of the Czech Statistical Office. 


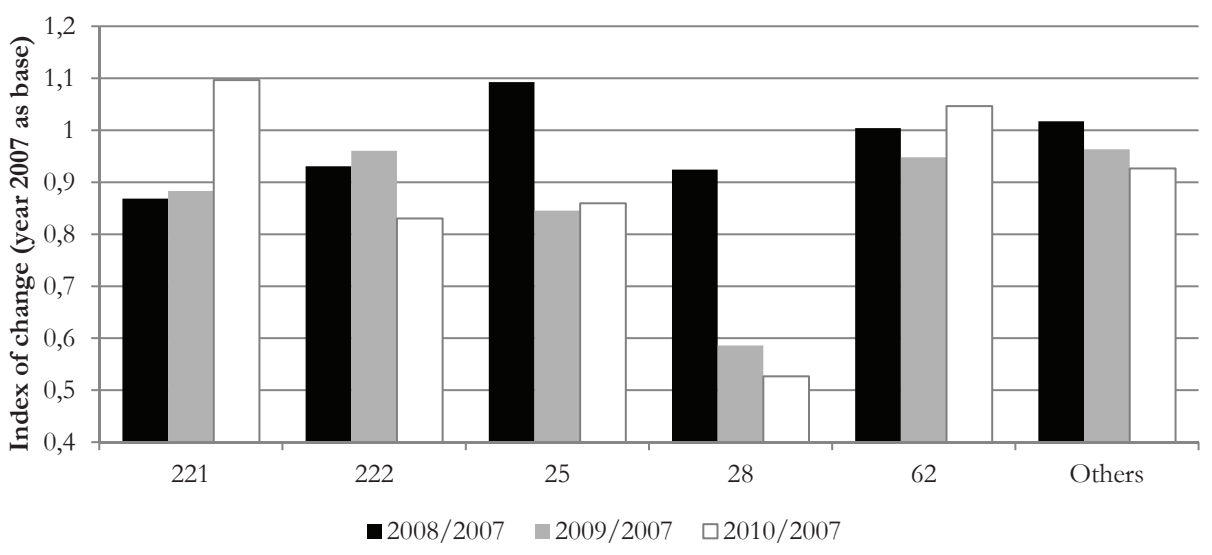

Note: 221 - Rubber production ( $\mathrm{N}=12) ; 222$ - Plastics industry ( $\mathrm{N}=24) ; 25$ - Metalworking $(\mathrm{N}=29)$; 28 - Machinery $(\mathrm{N}=25) ; 62$ - ICT programming $(\mathrm{N}=15)$

Fig. 2 - Changes in added values of particular industries; period 2007-2010; base year 2007. Source: own elaboration based on accounting documents of particular firms.

The second area of our interest is the assessment of innovative environment in the Zlín agglomeration. There is a long tradition of R\&D activities in the Zlín agglomeration. Historically, these activities were oriented on rubber production, plastics and chemical industry, and shoemaking. Also currently, R\&D activities are strongly concentrated in these sectors. This fact may be documented on distribution of R\&D results between faculties of the Tomas Bata University in Zlín, the most relevant institution of tertiary education in the Zlín agglomeration. In 2011, the share of the Technological Faculty in the total R\&D output of the university was more than $50 \%$ with another quarter added by the Faculty of Informatics. Moreover, R\&D infrastructure in the Zlín agglomeration is expected to be substantially strengthened after realization of three projects which were supported from the Research and Development for Innovations Operational Programme. These projects are oriented especially on plastics and chemical industry on one hand and on ICT based industries on the other. 


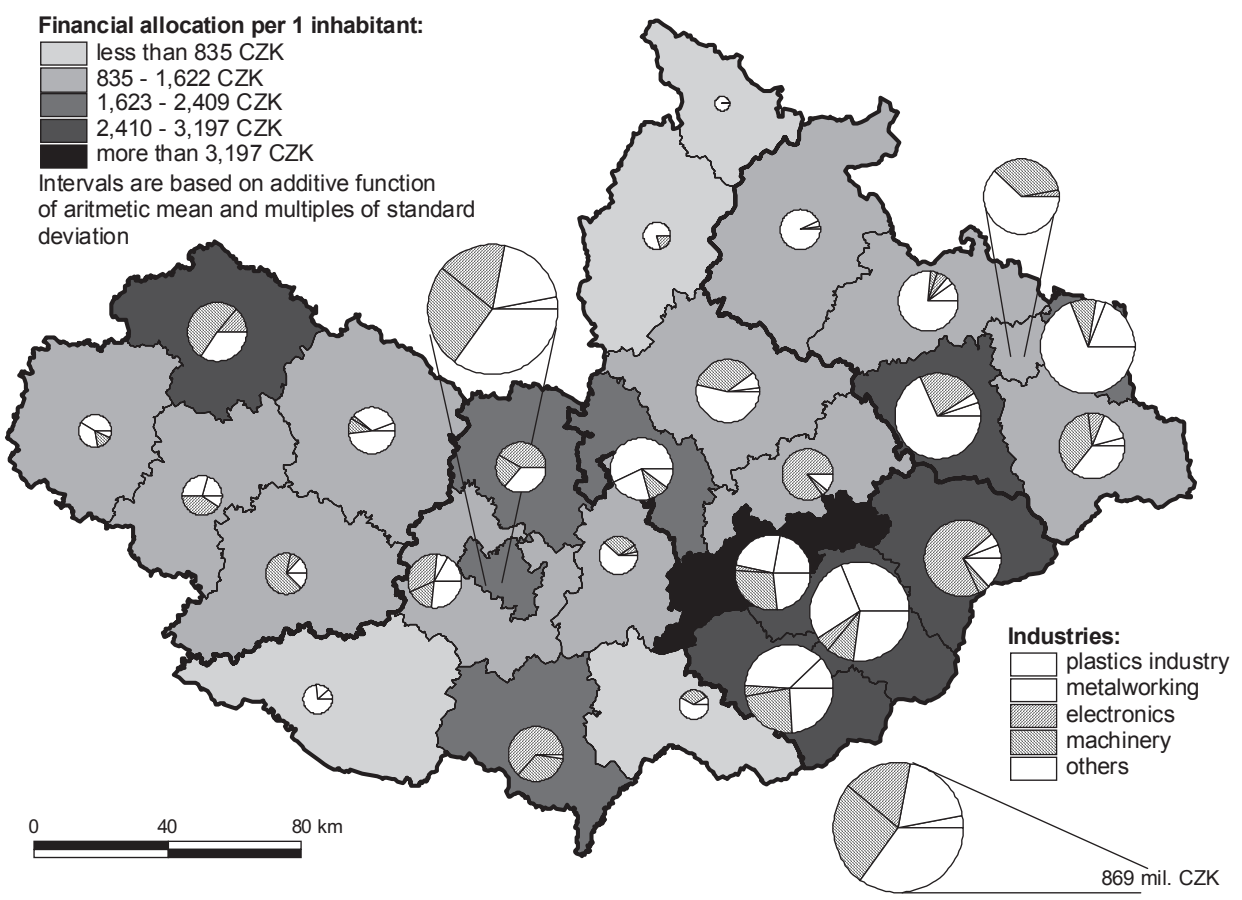

Fig. 3 - Spatial distribution of financial allocation - programs Potential and Innovation of Operational Programme Enterprise and Innovation; structure according to industries. Source: own elaboration based on information system of Operational Programme Enterprise and Innovation.

Finally, we complemented a rather qualitative analysis of innovative environment in the Zlín agglomeration by evaluation of innovative projects which were supported from the Operational Programme Enterprise and Innovation in Moravian counties. Note that the Zlín agglomeration is a natural core area of the Zlín County. Our evaluation was focused on absorption capacity of firms from particular industries. Fig. 3 shows the results. Our findings point at strong position especially of three industries in the Zlín County, or Zlín agglomeration respectively. These include rubber production, plastics industry, and metalworking.

To summarize, the match between innovation and territorial specialization seems to be substantiated in both, relatively strong traditional industries (e.g. rubber production and plastics industry) and newly emerging industries (e.g. ICT based industries). Just in these industries, the three typical features of the smart specialization concept - embeddedness, relatedness and connectivity (see McCann and Ortega-Argilés, 2011) - are expected to be developed creating assumptions for the implementation of the smart specialization concept.

Note that a special attention was given to the so called creative industries. This step was motivated by three reasons. First, there is a long tradition of film and other creative industries in the Zlín agglomeration (see also Bednář and Grebeníček, 2012 for a more detailed analysis). Second, there is potential of human capital development in creative industries because of creativity-oriented curricula taught at Tomas Bata University in Zlin. Third, creative industries are regarded 
as emerging industries for further development of the EU. Thus, a wide attention is given to creative industries in strategic document at the EU level.

\subsection{Smart specialization in the Zlín 2020 Strategy - strategic part}

The analytical part of the Zlín 2020 Strategy showed the importance of and relevant findings related to the smart specialization concept in the Zlín agglomeration. How were these findings implemented into the strategic part of the document?

Easy said the smart specialization concept is the leitmotif of strategic goals and measures of the thematic area "Economic Development and Labour Market". The main strategic goal of this thematic area is to support competitiveness of the Zlín City and Zlín agglomeration in accord with the smart specialization concept (Hájek et al., 2012). The relevance of the key industries for this concept identified in the analytical part is, in accord with the argumentation in McCann and Ortega-Argilés (2011), explicitly stressed. In addition, several related measures are added (compare with Hájek et al., 2012):

- First, it is accepted that smart specialization strategies are relevant at national and regional level. Therefore, we regard as essential to secure that formulation of these strategies will respect assumptions of the Zlín agglomeration for the smart specialization concept. Just in this phase, the "discovery" of suitable technological domains based on close cooperation in the Zlín agglomeration is anticipated. Note that the importance of ICT and creative solutions is stressed.

- Second, smart specialization is the leading concept for development of several support measures. These measures include e.g. applied research, virtual enterprise incubator or microcredit fund. Note that these measures are expected to contribute also to the stimulation of cooperation and knowledge exchange in the Zlín agglomeration. Specifically, the relationship between R\&D institutions and firms is stressed. Finally, multi-level cooperation of public institutions is strongly recommended.

- Third, the smart specialization concept is embedded also in other themes. These include the relationships between the smart specialization concept and the process of investors' attraction on one hand and between the smart specialization concept and education projects on the other.

Altogether, the smart specialization concept represents one of overarching frameworks how to shape further development and competitiveness of the Zlín City and Zlín agglomeration. Moreover, this concept has potential for creation of thematically integrated projects, fully respecting the fundamental idea of the programming principle.

\section{DISCUSSION AND CONCLUSION}

Smart specialization represents one of the leading concepts of the EU competitiveness now. Thus, the smart specialization concept may be regarded as a cornerstone for formulation of territorial strategic documents in their "competitiveness section". The third chapter of this article showed how the smart specialization concept was implemented in analytical and strategic parts of the Zlín 2020 Strategy - a conceptual document relevant for further development of the Zlín agglomeration. The following findings may be generalized in this regard: 
- In accord with the proposals for peripheral regions given in McCann and Ortega-Argilés (2011) the smart specialization concept for the Zlín agglomeration rests on innovation based diversification of traditional, locally embedded, large scale industries. The analysis showed a match between the enterprise and R\&D sectors in this regard. However, also emerging innovative domains focused of ICT and creative based industries were identified as suitable for smart specialization in the Zlín agglomeration.

- A number of measures, related to human capital development, stimulation of actors' cooperation and knowledge exchange, attraction of investors or applied research were suggested strictly in accord with the smart specialization assumptions of the Zlín agglomeration (compare with Foray, David and Hall, 2011, McCann and Ortega-Argilés, 2011). However, spatial dimension of the smart specialization concept is also considered, stressing the importance of a higher spatial level. Thus, the formulated measures should be linked to regional or even national smart specialization strategies.

To conclude, territorial competitiveness is often cited development concept of these days. There are a number of factors which influence territorial competitiveness. Thus, to find a suitable mix of these factors is a challenge practically for all territories. In this regard, smart specialization represents a politically influential concept now. This article demonstrated how the smart specialization concept may be followed in preparing strategic development documents, using the Zlín 2020 Strategy as a case study. In this regard, the smart specialization concept was used as the leading framework for formulation of strategic goals and measures related to thematic area "Economic Development and Labour Market". Moreover, this formulation was based on the assessment of the themes relevant for the smart specialization concept - innovative environment and economic base (see McCann and Ortega-Argilés, 2011 for guidelines). Altogether, the Zlín 2020 Strategy may be perceived as some inspiration how to link scholar approaches with daily practice of public administration.

\section{Acknowledgement}

Authors are thankful to Technology Agency of the CR (TA CR), programme OMEGA, project No. TD010158 for financial support to carry out this investigation.

\section{References}

1. Barca, F. (2009). An Agenda for a Reformed Cohesion Policy. A Place-based Approach to Meeting European Union Challenges and Expectations. Brussels: European Commission.

2. Bednář, P., \& Grebeníček, P. (2012). Mapping creative industries in the Zlín region. Journal of Competitiveness, 4(1), 20-35. http://dx.doi.org/10.7441/joc.2012.01.02

3. Benzaquen, J. et al. (2012). A competitiveness index for the regions of a country. Cepal Review, 102, 67-84.

4. Bourne, A. K. (2007). Regional Europe. In European Union. Politics (pp. 287-303). Oxford: Oxford University Press.

5. Camagni, R., \& Capello, R. (2013). Regional innovation patterns and the EU regional policy reform: towards smart innovation policies. Growth and Change, 44(2), 355-389. http:// dx.doi.org/10.1111/grow.12012 
6. Dudensing, R. M. (2008). Benchmarking Regional Competitiveness: the Role of a Region's Economic Legacy in Determining Competitiveness. Clemson: Clemson University.

7. European Commission (EC, 2010). Europe 2020 Flagship Initiative Innovation Union. SEC (2010) 1161. Brussels: European Commission.

8. European Commission (EC, 2012). Elements for a Common Strategic Framework 2014 to 2020. Commission Staff Working Document SWD (2012) 61. Brussels: European Commission.

9. Foray, D., David, P. A., \& Hall, B. H. (2011). Smart Specialization. Lausanne: Ecole Polytechnique Fédérale De Lausanne.

10. Grabher, G. (1993). The weakness of strong ties. The lock-in of regional development in the Ruhr area. In The Embedded Firm (pp. 255-277). On the Socioeconomics of Industrial Networks. London: Routledge.

11. Hájek, O., Novosák, J., \& Hovorková, Z. (2011). Inovace a region: klastry a regionální inovační systém Zlínského kraje. [Innovation and region: clusters and regional innovation system of the Zlínský region]. E+M Ekonomie a Management, 14(2), 31-44.

12. Hájek, O. et al. (2012). Strategie rozvoje statutárního mèsta Zlína do roku 2020 - Zlín 2020. Náurhová cást. [The Zlín City Development Strategy 2014-2020 - Zlín 2020. Strategic Part]. Zlín: Tomas Bata University in Zlín.

13. Isaksen, A. (2001). Building regional innovation systems: is endogenous industrial development possible in the global economy? Canadian Journal of Regional Science, 24(1), 101121.

14. Kitson, M., Martin, R., \& Tyler, P. (2004). Regional competitiveness: an elusive yet key concept? Regional Studies, 38(9), 991-999. http://dx.doi.org/10.1080/0034340042000320816

15. Maillat, D. (1998). Innovative milieu and new generations of regional policies. Entrepreneurship \& Regional Development, 10(1), 1-16. http://dx.doi.org/10.1080/08985629800 000001

16. McCann, P., \& Ortega-Argilés, R. (2011). Smart Specialisation, Regional Growth and Applications to EU Cohesion Policy. Groningen: University of Groningen.

17. Nijkamp, P. (2009). Regional development as self-organized converging growth. In Spatial Disparities and Development Policy (pp. 265-282). Washington: The International Bank for Reconstruction and Development, World Bank.

18. Pavelková, D., \& Jirčíková, E. (2008). Klastry jako nástroj zvýšení konkurenceschopnosti firem. [Clusters as a tool for increasing competitiveness of firms]. E+M Ekonomie a Management, 11(3), 62-72.

19. Phelps, N. A. (2004). Clusters, dispersion and the spaces in between: for an economic geography of the banal. Urban Studies, 41(5/6), 971-989. http://dx.doi.org/10.1080/0042098 0410001675887

20. Scott, A. J., \& Storper, M. (2003). Regions, globalization, development. Regional Studies, 37(6\&7), 579-593. http://dx.doi.org/10.1080/0034340032000108697a

21. Skokan, K. (2010). Inovační paradox a regionální inovační strategie. [Innovation paradox and regional innovation strategies]. Journal of Competitiveness, 2(2), 30-46.

22. Žižka, M. (2008). Vliv klastrů na konkurenceschopnost podniků v České republice. [Impact of clusters on firm competitiveness in the Czech Republic]. Ekonomický casopis, 56(1), 39-52. 


\section{Contact information}

Jirú Novosák, Oldrich Hájek, Petr Zabradník, Jana Nekolová

Tomas Bata University in Zlin, Faculty of Management and Economics

Mostni 5139, 76001 Zlin, Czech Republic

E-mail:novosak@fame.utb.cz; bajek@fame.utb.cr. 